\title{
Goodman, Michael \& Colin Sage (eds.), Food Transgressions: Making Sense of Contemporary Food Politics, Farnham: Ashgate. 2014.
}

\author{
Recensão de Ana Almeida \\ CETAPS/ Universidade do Porto
}

Organizada por Michael K. Goodman (King's College London) e Colin Sage (University College Cork), a presente coletânea integra onze artigos de investigadores das disciplinas da Geografia, Sociologia, Epidemiologia e Saúde Pública, Gestão e Sustentabilidade, e explora as dinâmicas das cadeias alimentares contemporâneas através de um conceito comum: a transgressão. A premissa deste volume é relacionar as múltiplas variações das transgressões a nível alimentar, bem como de geografias políticas, com a (re)configuração de cadeias alimentares através de modelos alternativos. Recorrendo a diferentes metodologias e exemplos práticos a nível local, nacional e transnacional, os autores analisam estratégias para transgredir - e até não transgredir - os limites e fronteiras do status quo das políticas contemporâneas relativas à alimentação. Tendo em conta a complexificação dos vínculos entre os vários agentes envolvidos, bem como a fluidez das fronteiras entre natureza, cultura e tecnologia, é objetivo último desta obra criar um espaço de entrecruzamento de várias áreas científicas, evidenciando a interdisciplinaridade do conhecimento produzido no âmbito dos Estudos sobre a Alimentação. 
0 ponto de partida do presente volume é a reconceptualização do próprio termo "transgressão" para acomodar não apenas a reavaliação das complexas relações económicas e políticas inerentes a um mundo globalizado, mas também as questões de ordem moral e ética que daí têm emergido. Subjacentes ao conceito de transgressão estarão, segundo os organizadores do volume, as noções de intenção, intencionalidade, prática e processo, por um lado, e da ação capilar de poder, por outro. Concomitantemente, os editores defendem que a compreensão das dinâmicas alimentares contemporâneas assenta na análise dos comportamentos transgressivos a nível ético, governativo e geográfico por parte de quem produz e de quem consume, dando por isso grande atenção ao possível surgimento e/ou reconfiguração de novas espacialidades físicas, sociais e institucionais, quer a nível do quotidiano quer a nível político. Os diferentes artigos exploram, em particular, algumas das mais recentes configurações transgressivas nas práticas alimentares contemporâneas denominadas de "alternativas," destacando-se as de comércio justo ("Fairtrade"), o movimento Slow Food e a produção biológica e/ou da responsabilidade de comunidades locais, transgressivas em relação aos hábitos alimentares tradicionais, amplamente controlados pelas grandes retalhistas e dependentes do consumo de carne. A reflexão recai, sobretudo, sobre a forma como as estruturas de poder e a geopolítica global influenciam e são influenciadas por esses movimentos alternativos, que se afirmam simultaneamente através de transgressões discursivas e materiais. Compreendê-las implica pois, por um lado, explorar qual o verdadeiro potencial dessas alternativas para o futuro, e, por outro, prever as possíveis consequências da sua relação com os grandes produtores e cadeias de supermercados.

De entre os onze artigos, será de salientar o texto assinado por Amanda Berlan e Catherine Dolan sobre o movimento Fairtrade, "Of Red Herrings and Immutabilities: Rethinking Fairtarde’s Ethic of Relationality among Cocoa Producers," que dá o mote para a defesa da necessidade de se proceder a uma reavaliação do impacto efetivo da ética do cuidado ("ethics of care") que tem sustentado algumas das práticas transgressivas apresentadas no volume. Se, por um lado, a ética do cuidado é transgressiva porque é relacional, colocando assim em causa os sistemas produtivos convencionais dependentes de 
“processos complexos e espacialmente dispersos", importará, por outro lado, questionar a forma como (sobretudo) as grandes cadeias de supermercados têm vindo a criar espaços éticos através de estratégias de "negócio ético" ("ethical business"), que têm potenciado uma atitude pouco interventiva a nível ético (uma "ethic of detachment") por parte dos consumidores.

Num outro artigo, "Making and Un-Making Meat: Cultural Boundaries, Environmental Thresholds and Dietary Transgressions," Colin Sage evidencia as mudanças alimentares que privilegiam o consumo de carne ("meatification"), assim como as consequências ambientais da sua produção massiva. A ênfase recai sobre o papel pedagógico que os países do Norte poderão assumir em relação aos países do hemisfério sul, apostando na transformação dos discursos divergentes entre as necessidades alimentares reais e as "expectativas culturais e materiais" de ambas as partes. Em consonância com um artigo anterior na coletânea ("Making Meat Collectivities: Entanglements of Geneticisation, Integration and Contestation in Livestock Breeding" de Lewis Holloway et al.), Sage denuncia o enraizamento pernicioso das práticas produtivistas atuais na franca expansão da engenharia genética em vários domínios de toda a cadeia produtiva da carne. Por fim, o autor sugere uma tendência dupla a nível da "demeatification" através dos movimentos alternativos "flexitarianism" e vegetarianismo.

Numa apreciação de síntese, os diferentes artigos evidenciam a dificuldade dos vários agentes económicos - produtores, retalhistas e consumidores - em forjar ligações comerciais e afetivas fortes, uma vez que que interagem, sobretudo, através de relações de mercado abstratas. É ainda de salientar que a maioria dos casos de estudo remete para o mercado britânico, à escala local, nacional ou transnacional, havendo por isso lugar para um trabalho de identificação, no futuro, dos comportamentos transgressivos em outros países com estruturas produtivas e relações comerciais distintas. 